\title{
The pleasure of immersion: Some thoughts on how The Singing Detective sustains narrative
}

\author{
Anne Karpf, London Metropolitan University \\ $\underline{\text { Post-print from Journal of Screenwriting, vol.4, no.3, } 2013}$
}

\begin{abstract}
This article argues that while Dennis Potter's television drama series 'The Singing Detective' is commonly celebrated for its multilayered narrative and the post-modern way that it played with genre, another of its critical features has remained relatively neglected: the sustained narrative pleasure that it afforded. It suggests that Potter allowed viewers the deep immersive experience of realist TV drama and storytelling, even while he was experimenting with narrative, so providing a bridge between modernist and traditional forms, and rewarding viewers (who had to try and integrate the series' different fragments and layers into some sort of quasi-cohesive narrative) with abundant dramatic gratification. Narrative, it claims, is not effaced, only displaced, partly onto the central character of Marlow, whose subjectivity unifies the fragmented narrative. Potter broke radically with the conventions of TV medical drama, and the painful experience of Marlow-as-patient acts as another binding agent.
\end{abstract}

\section{Keywords}

The Singing Detective

narrative

immersion

medical drama

\section{Introduction}

The Singing Detective (TSD, 1986), Dennis Potter's six-part drama series first broadcast on BBC TV in 1986, is commonly celebrated for its multi-layered narrative and the way 
that it played with genre. It has been called the Citizen Kane of the television miniseries (King 2004, cited in Creeber 2007: 1), one of the significant works of twentieth-century British modernism (Caughie 2000: 20) and even compared to James Joyce's Ulysses (Gilbert 1995: 263). Critics have analysed its use of pastiche, the way it drew attention to the writing process, its anti-realist tics and tropes, along with its complexity and the new television language that Potter attempted to forge (Creeber 2007: 34). But I want to suggest that, while TSD was innovative in all the above ways, commentators have overstressed its experimentation with narrative and, as a result, the traditional narrative pleasures that it afforded have remained relatively neglected.

I too remembered TSD for the satisfying way Potter detoured from detours in a manner that today would be termed postmodern, if not hypertextual. And yet I simultaneously remembered the strong spine of the piece, its narrative backbone - Philip Marlow and his awful predicament: the abject adult Marlow, inside his armature of damaged skin; the boy Marlow who sees and says what he is not supposed to; and the women - monstrous, seductive and occasionally gentle. The series, I recalled, led the viewer from Marlow in hospital, suffering from a disfiguring skin condition, back through key moments of his childhood, and forward again to the resolution, when he is finally able to walk unaided from the ward.

When, on the 25th anniversary of its original screening, I watched the series again, my memories were both confirmed and challenged. Of course re-viewing a 'milestone' series is a complex enterprise: it invites a review of so many factors, including memory itself. What we remember of a text last encountered a quarter of a century before is the version that we, and not the director, edited: our memory has pulled threads from the 
drama and rewoven them into something else. A reviewing, therefore, becomes not just a reappraisal of the original but also of ourselves - the viewers we were then - as well as the context within which the text was created. In some sense, then, reviewing TSD becomes an encounter between four texts - the series, the era in which it was made, the viewers we used to be and the viewers we are now.

\section{Pace}

One of the most striking aspects of $T S D, 25$ years on, is its slow pace. Accustomed as we are to the fast cross-cutting of modern visual media - the average length of shot in films like Batman Begins (2005) and The Bourne Ultimatu[K1]m (2007) is less than two seconds (Sandhu 2012), ${ }^{1}$ and television drama feels as if it has been similarly accelerated - the length of scene in TSD seems extraordinarily leisurely. I use the word 'scene' advisedly, because each episode in TSD is divided into a number of extended, almost self-contained scenes, which regularly exceed five minutes and, in places feel as if they belong more in a stage play than television, even if they are sometimes briefly interrupted by other scenes. In Episode 2, for example, the first exchange between Marlow and Dr Gibbon lasts six minutes and, if you exclude the brief cutaway to a conversation between the two mysterious men on Hammersmith Bridge and the subsequent glimpse of Binney making love to Sonia, it extends for 13 minutes in total. This is languid in the extreme.

Yet its unhurried pace, I want to suggest, is not only historically determined - this was the pace of television drama in the 1980 s - but also represents a choice by Potter. By juggling with genre and shifting between layers of narrative, Potter was making enormous demands on viewers - demands they were more likely to expect if they had consciously chosen to see an experimental film in the cinema, rather than switch on the 
television and see a drama series transmitted into their home. His viewers, like Marlow himself, were required to follow clues and trails, and assemble the constituent parts into something resembling a continuous narrative, even while they submitted to narrative confusion. After my original viewing, so thoroughly did I assemble parts into a whole that I had remembered the scene in Episode 4 in which the terrifying schoolmistress tries to discover the identity of the child who had defecated on her desk, as a long, single, intense passage whereas, in reality, it was divided into five segments, which thereby served to increase the dramatic tension. In my imagination I had remembered them into a continuous sequence.

While Potter delighted in challenging and stretching dramatic convention, he must have intuitively understood the dangers of generating too much anxiety in viewers. After all, he had chosen to write for the most popular, accessible dramatic medium of the day and, if his work was not to be confined to a modernist ghetto, needed to be able to speak to a mass audience. Running scenes at length and sustaining dramatic encounters provided viewers with all the pleasures of immersion characteristic of realist television drama and soap opera, with the opportunity to embed themselves in the story. Indeed there are times, watching $T S D$, when you forget about all its narrative sleights of hand, and become completely absorbed by the interplay between a pair of characters, so that the shift of scene would feel almost violent were it not for the gentle cross-fades, pans and musical passages that assist the transition.

\section{The hero}

Potter insisted that, in Brechtian fashion, he did not want viewers to identify with his characters and, to this end, tried to make his central character in TSD as unheroic and 
unlikeable as possible. Nevertheless, at the heart of TSD, in every sense, is Marlow himself, as Potter himself acknowledged: all the events in TSD always return to 'one point of contact... [Marlow] in a hospital bed' (Cook 1995: 217). Moreover, J. Caughie observed, 'The fragments are unified by the central consciousness of Marlow... If it is not a contradiction in terms, then, Potter's modernism is of the "classicist" mode rather than avant-gardiste' (2000: 176).

Director Jon Amiel is commonly credited with making Marlow into a warmer, more sympathetic character (Cook 1995: 220), although his very prickliness is understood, by both viewers and within the narrative itself, as a direct expression of his pain. In fact Marlow's improving skin is so grotesque at the start that this viewer at least had to resist the fantasy urge to lean forward and peel off the flakes half-attached to the wretched man's face, which acts as a barometer of his growing psychic health and integration and thereby provides a developing narrative of its own.

Marlow's subjectivity, fragmented though it is, binds TSD together. By constantly returning to Marlow-in-bed, Potter anchors his narrative, providing viewers with a compass with which to orient themselves. He also implicitly makes clear that not all the segments - the noirish gumshoe sequences, the Binney (or Finney, as he later turns out to be called)-Nicola interchanges - are of equal importance. TSD is awash with flashbacks, but it needs someone to do the flashing back, and that someone is Marlow.

In this sense, TSD is absolutely character- and emotion driven. No amount of narrative trickery can obscure the depth of feeling in either young or adult Marlow. He suffers, and the viewer suffers with him. 'Help me', he asks desperately in Episode 1. 
'I've reached the end', he tells the consultant. Michael Gambon's stunning performance, moving between acid wit and psycho-physical pain, is the portal into the series. While Potter disrupts the narrative, he never loses sight of the overarching metanarrative: he does not efface narrative, only displaces it (Cobley 2001: 178). Though he challenges the primacy of a single, unifying narration, he confers something of that power onto his central character himself. If Marlow's narrative takes the form of a mosaic, rather than a linear chain of causality, it still leads inexorably to resolution - a finale of psychic integration ('I think I've cracked this case, folks', Potter 1986: 248), signalled by a shoot-out, and Marlow and Nicola walking off into the sunset. Potterian irony, maybe (and Amiel had to dissuade him out of finally depicting the whole story as a dream), but the need for some kind of narrative completion and summation evidently proved irresistible, as well as thematically necessary.

\section{Links}

A fragmented narrative can be seen as an anti-realist rejection of a unified subject, but in TSD it can also be regarded as an expression of what the psychoanalyst Wilfred Bion called 'attacks on linking': 'the destructive attempts that a patient makes on anything which is felt to have the function of linking one object to another' ([1959] 1988: 87). Bion argues that 'in this state of mind emotion is hated; it is felt to be too powerful to be contained by the immature psyche' ([1959] 1988: 100). Marlow's sessions with Dr Gibbon dramatize such attacks. 'Are you going to keep on like this?' Marlow demands with flinty sarcasm when Dr Gibbon tries to suggest that the clues in Marlow's detective story reveal not only the murderer but also the victim. 'Is this what you think will start me off talking to you?' (Potter 1986: 52). 'Stop pissing in the wind. Stop listening to the 
sound of your own voice. Stop confusing wisdom with smugness' (Potter 1986: 56). By

Episode 6, in the last session with Dr Gibbon, Marlow is finally able to tolerate Dr

Gibbon's link-making. He has now developed the capacity to cry, and hence to stand up.

It is this which justifies the narrative resolution, and makes it not only dramatically but also psychologically satisfying. Marlow has managed to bring the fragments of both his life, and the series, together.

Potter and Amiel - who not only directed the series but also played a central role in the production of the final script - used a number of other techniques as binding agents. Among them are recurring images, which work not only as key moments of psychological trauma but also as a series of visual vantage points - most obviously young Marlow in the tree, from which he witnesses the primal scene but also surveys the sweep of the Forest of Dean, Marlow's life and the whole series. This visual leitmotif pulls the reader back to the terrain from which all the other sorties follow. The series' use of popular music has been much discussed, but music is also used as an aural signpost, as well as a careful editing tool to segue from one genre to another, and splice the layers together. These techniques not only bridge together the different segments and narrative shifts but also have a meta-function, in some sense serving as a bridge between the series' modernist and traditional forms of storytelling.

As has been argued, deconstruction of old conventions does not invariably involve deconstruction of a genre but can, instead, bring about their revitalization (Onega and Landa 1996). 'Metafiction parodies and imitates as a way to a new form... It does not necessarily involve a movement away from mimesis, however, unless by that term is meant only a rigid object-limitation or behaviourist-realistic motivation’ (Hutcheon 1984. 
Potter's use of genre - film noir, the Hollywood musical, hospital soap opera, etc. offers viewers instant narrative pleasure as we recognize their key features, exaggerated and mocked. And yet Potter never uses the genres simply as empty signs, or a way of flattering the viewer able to decode them, but also milks them for their dramatic potential. The foggy street scenes by Hammersmith Bridge, the two mysterious men, the menacing encounters between Binney and Sonia - we savour and are drawn into these scenes even as Potter ironizes them. The sequence when Sonia's lifeless body is fished out of the Thames is not merely a signifier for the gumshoe movie, the opportunity for ersatz sentiments or kitsch reactions. Such scenes also become containers for the deep emotions - the psychic pain, anger and desire - that Marlow-in-bed cannot not contain, and so also provide powerful dramatic gratification. Watching $T S D$, for all its dazzling antics, is also an affecting experience.

\section{The ward}

The hospital setting is the bedrock of the piece, the fulcrum from which all the other strands depart and return. Potter's template was the hospital soap opera, which he had already satirized twenty years earlier in Emergency Ward 9, a Thirty-Minute Theatre play set in the male ward of a London hospital, which among other things took aim at the idealized view of medicine and doctors in television drama series such as Emergency Ward 10 (EW10) (Carpenter 1998: 184). Potter knew that many of his viewers would be familiar with $E W 10$, as well as with the bedpan humour of the 'Carry On' films. He also pointedly calls one of the doctors in TSD Dr Finlay, after the medical series Dr Finlay's Casebook. 
But the doctors in TSD are not the usual doctors of television medical dramas benevolent, avuncular healers, their curative abilities matched only by their intuitive empathy (Karpf 1988), but imperious, inhumane men who hide behind jargon. Nor are its patients passive, grateful, unsexed, merely the site for displays of medical expertise and heroism. TSD problematized doctor-patient communication just as a 'consumer' critique of medicine, challenging the medical model, was gaining traction (Karpf 1988). It was broadcast two years before the publication of Arthur Kleinman's major book, The Illness Narratives (1988), which compared the lived human experience of illness - its social, cultural and personal meanings - with a disease model, where people became cases with symptoms, and moved from being the subject of medical enquiry to its object. Most of TSD's doctors simply refuse any engagement with Marlow's subjectivity: as is most evident in the 'Dry Bones' musical sequence, he remains firmly their object.

In just one medical respect, Potter permitted himself to fall back on idealization. Dr Gibbon, described as a psychotherapist, may match Marlow for sardonic wit, but he displays just as much empathy as Dr Kildare, and seems to be able to offer the kind of open-ended, extensive sessions that would have been remarkable to find in the NHS, even at its most flush.

TSD was one of the first television medical dramas to portray the indignity, sense of humiliation and helplessness of chronic illness: the patient's experience is put centre stage and, since (in the 1980s) hospital stays could be long (though rarely, perhaps, as long as that of Marlow and some of his fellow patients on the ward), the image of Marlow-in-bed - receiving treatment, visitors or just recollecting - could justifiably serve 
as the chief recurring scene by which viewers could reorient themselves after the forays into the various genre segments.

\section{Conclusion}

While Potter's experimental techniques have been widely applauded, less attention has been paid to some of the more traditional narrative satisfactions offered by TSD. Its slow pace enabled viewers to steep themselves in plot and character in each of its extended scenes and gave them a sustained dramatic experience - the sort of pleasures of immersion that viewers would expect in realist drama. Even the different genres were exploited not just for their ironic potential but also to excite, or throw into relief, real feeling. Despite Potter's protests, his central character, Marlow, became, in Gambon's glittering performance, a deeply affecting character, to whom the narrative regularly returned, and whose subjectivity bound together the different fragments. As Marlow integrated the different parts of his life that he had formerly split off, the narrative itself came together, moving towards a resolution that not only satisfied the demands of classic drama but also was psychologically convincing. Recurring visual images and music helped create links for the viewer, even while Marlow was attacking them. Marlow-inbed became the visual lynchpin, and the indignity and pain of chronic illness a theme that helped bind the whole together.

The tension between the fracturing of the narrative and these cohering techniques and qualities, the way in which TSD moved between dissolution and integration, perhaps helps to explain why it felt so rich, so engaging and, ultimately, so complete.

I am grateful to Paul Cobley for his useful comments on this article 


\section{References}

Bion, W. ([1959] 1988), ‘Attacks on linking’, in E. Bott Spillius (ed.), Melanie Klein

Today, London: Routledge[K2], pp87-101.

Carpenter, H. (1998), Dennis Potter, London: Faber.

Caughie, J. (2000), Television Drama: Realism, Modernism, and British Culture, Oxford: Oxford University Press.

Cobley, P. (2001), Narrative, London: Routledge.

Cook, J. R. (1995), Dennis Potter: A Life on Screen, Manchester: Manchester University Press.

Creeber, G. (2007), The Singing Detective, London: British Film Institute.

Gilbert, W. G. (1995), Fight and Kick and Bite: The Life and Work of Dennis Potter, London: Hodder and Stoughton.

Hutcheon, L. (1984), 'Modes and forms of narrative narcissism: Introduction of a typology', in S. Onega and J. Landa (eds), Narratology: An Introduction, London:

Longman[K3], pp203-214- 
Karpf, A. (1988), Doctoring the Media: The Reporting of Health and Medicine, London: Routledge.

Kleinman, A. (1988), The Illness Narratives, New York: Basic Books.

Onega, S. and Landa, J. (1996), Narratology: An Introduction, London: Longman.

Potter, D. (1986), The Singing Detective, London: Faber.

Sandhu, S. (2012), 'Reel time', The Guardian, 10 March[K4], p18.

The Singing Detective (1986), author Dennis Potter, director Jon Amiel, $\mathrm{BBC}_{[\mathrm{K} 5]} /$ Australian Broadcasting Corporation for BBC1, UK, tx. 16 November 1986-21 December 1986, six-part serial, approximately 70 minutes each episode.

\section{Contributor details}

Anne Karpf is Reader in Professional Writing and Cultural Inquiry at London Metropolitan University. A broadcaster, journalist and columnist for The Guardian and other national newspapers, her books include Doctoring The Media: The Reporting of Health and Medicine (Routledge, 1988) and The Human Voice (Bloomsbury, 2006; Ehrenwirth, 2007; Autrement, 2008; Soshisha, 2008). She is currently researching the 
BBC broadcasts of Donald Winnicott (1943-1962), the emergence of the cancer memoir and Holocaust historiography.

\section{Contact:}

Faculty of Social Sciences and Humanities, London Metropolitan University, 166-20

Holloway Road, London, N7 8DB, UK.

E-mail: A.Karpf@londonmet.ac.uk

Note

${ }^{1}$ Although there are signs of a backlash against velocity, even in feature films aspiring to edge out of art cinema into the mainstream. Steve McQueen, for instance, runs scenes for seventeen minutes in Hunger and Shame. 